\title{
PENGARUH KOMUNIKASI, ETIKA KERJA DAN KEDISIPLINAN TERHADAP PRODUKTIVITAS KERJA PEGAWAI KANTOR CAMAT KECAMATAN SIBOLGA KOTA
}

\author{
${ }^{1}$ Ittoki Josua Pakpahan, ${ }^{2}$ Rudi Herwin, ${ }^{3}$ Imelda Susanti, ${ }^{4}$ Emmy Fauziah Marpaung, ${ }^{5}$ Novita Rizki Harahap \\ $1,2,3,4,5$ Universitas Islam Sumatera Utara \\ ${ }^{1}$ ittoki..josuahrp@gmail.com, ${ }^{2}$ rudi.herwin@gmail.com, ${ }^{3}$ imelda.susanti@gmail.com, ${ }^{4}$ emmy.fauziah@gmail.com, \\ 5novita.rizki@gmail.com
}

\begin{abstract}
This research aims to determine and analyze : 1) the effect of communication on the productivity employees of the Kantor Camat Sibolga Kota; 2) the effect of work ethics on the productivity employees of the Kantor Camat Sibolga Kota employees; 3) the influence of discipline on the productivity employee of the Kantor Camat Sibolga Kota; and 4) the effect of communication, work ethics and discipline on the productivity employees of the Kantor Camat Sibolga Kota. This type of research is associative research, with a sample of 56 people. The results showed : 1) communication had a positive and significant effect on the productivity employee of the Kantor Camat Sibolga Kota; 2) Work ethics have a positive and significant effect on the productivity employees of the Kantor Camat Sibolga Kota employees; 3) Discipline has a positive and significant effect on the productivity employees of the Kantor Camat Sibolga Kota employees; 4) Simultaneous communication, work ethics and discipline have positive and significant effect on the productivity employees of the Kantor Camat Sibolga Kota employees. Productivity employees can be influenced by communication, work ethics and discipline by $61.8 \%$. While the remaining $38.2 \%$ is influenced by other variables not examined in this research.
\end{abstract}

Keywords : Communication, Work Ethics, Discipline, Productivity Employees.

ABSTRAK : Penelitian ini bertujuan untuk mengetahui dan menganalisis : 1) pengaruh komunikasi terhadap produktivitas kerja pegawai Kantor Camat Kecamatan Sibolga Kota; 2) pengaruh etika kerja terhadap produktivitas kerja pegawai Kantor Camat Kecamatan Sibolga Kota; 3) pengaruh kedisiplinan terhadap produktivitas kerja pegawai Kantor Camat Kecamatan Sibolga Kota; dan 4) pengaruh komunikasi, etika kerja dan kedisiplinan terhadap produktivitas kerja pegawai Kantor Camat Kecamatan Sibolga Kota. Jenis penelitian ini adalah penelitian asosiatif, dengan sampel berjumlah 56 orang. Hasil penelitian menunjukkan : 1) komunikasi berpengaruh positif dan signifikan terhadap produktivitas kerja pegawai Kantor Camat Kecamatan Sibolga Kota; 2) Etika kerja berpengaruh positif dan signifikan terhadap produktivitas kerja pegawai Kantor Camat Kecamatan Sibolga Kota; 3) Kedisiplinan berpengaruh positif dan signifikan terhadap produktivitas kerja pegawai Kantor Camat Kecamatan Sibolga Kota; 4) Komunikasi, etika kerja dan kedisiplinan secara simultan berpengaruh positif dan signifikan terhadap produktivitas kerja pegawai Kantor Camat Kecamatan Sibolga Kota. Produktivitas kerja pegawai mampu dipengaruhi oleh komunikasi, etika kerja dan kedisiplinan sebesar 61,8\%. Sedangkan sisanya sebesar 38,2\% dipengaruhi variabel lain yang tidak diteliti dalam penelitian ini.

Kata kunci : Komunikasi, Etika kerja, Kedisiplinan, Produktivitas kerja.

\section{Pendahuluan}

Peningkatan kualitas sumber daya pegawai sangat diperlukan secara terencana, terarah dan Produktivitas kerja merupakan suatu hasil kerja dari seorang pegawai, hasil kerja pegawai merupakan suatu proses bekerja dari seorang pegawai dalam menghasilkan suatu barang maupun jasa. Peningkatan produktifitas kerja pegawai merupakan suatu strategi yang dapat diterapkan organisasi untuk mencapai tujuan. Menurut Hasibuan (2010:157) bahwa produktivitas adalah perbandingan antara output 
(hasil) dengan input (masukan). Jika produktivitas naik hanya dimungkinkan oleh adanya peningkatan efisiensi (waktu, bahan dan tenaga) dan sistem kerja, teknik produksi, serta peningkatan keterampilan kerja pegawai dari tenaga kerjanya.

Terkait dengan hal tersebut, maka organisasi dituntut untuk dapat menciptakan lingkungan kerja yang aktif yang sangat berperan dalam efektivitas dan efisiensi kerja organisasi, sehingga dapat menunjang kelancaran individu untuk meningkatkan produktivitas kerja. Salah satu cara untuk meningkatkan produktivitas kerja adalah dengan memperbaiki komunikasi yang terjalin dalam suatu organisasi serta penguatan etika kerja dan kedisiplinan pegawai.

Komunikasi merupakan salah satu aspek terpenting namun juga kompleks dalam kehidupan manusia. Manusia sangat dipengaruhi oleh komunikasi yang dilakukannya dengan manusia lain, baik yang sudah dikenal maupun yang tidak dikenal sama sekali. Komunikasi memiliki peran yang sangat vital bagi manusia, maka dari itu, setiap orang harus memberikan perhatian yang seksama terhadap komunikasi.

Terwujudnya tujuan suatu organisasi tidak akan lepas dari komunikasi individu-organisasi di dalam kelompok formal maupun informal dari suatu organisasi. Komunikasi dalam organisasi memungkinkan setiap pegawai organisasi melaksanakan pekerjaannya secara lebih pasti. Informasi pada dasarnya dibutuhkan oleh semua orang yang mempunyai perbedaan kedudukan dalam suatu organisasi. Komunikasi juga dapat mengantisipasi dan mengatasi malasah atau konflik yang terjadi dalam organisasi.

Pada umumnya organisasi adalah sekelompok masyarakat yang saling bekerja sama untuk mencapai suatu tujuan tertentu dan komunikasi adalah perekat yang memungkinkan kelompok masyarakat tersebut secara bersama-sama melakukan fungsinya dengan baik. Oleh sebab itu, Komunikasi merupakan kegiatan yang sangat penting dalam berorganisasi. Hasil penelitian seorang pakar komunikasi menyimpulkan bahwa sekitar $75 \%$ - 90\% waktu kerja digunakan pimpinan atau manajer untuk berkomunikasi. Jika dua orang atau lebih bekerja sama maka perlu adanya komunikasi antarmereka. Makin baik komunikasi mereka maka akan baik pula kerjasama mereka.
Hubungan komunikasi yang terjalin baik antara pimpinan dan pegawai serta antara pegawai yang satu dengan pegawai yang lain, merupakan salah satu kunci keberhasilan dalam mencapai tujuan organisasi yang telah ditetapkan. Pelaksanaan kegiatan suatu organisasi tanpa adanya komunikasi yang baik dapat mengakibatkan tidak efektif dan efisiennya kinerja dalam suatu organisasi dan akan berpengaruh langsung terhadap kegiatankegiatan lainnya, sehingga proses keseluruhan kegiatan didalam organisasi akan terhambat. Konflik bahkan sering terjadi dalam organisasi disebabkan oleh komunikasi yang kurang baik.

Kenyataannya sekarang, seluruh dunia kerja yang akan kita masuki sedang berubah secara dramatis. Jenis pekerjaan yang kita lakukan, alat yang kita gunakan, bentuk manajemen, lingkungan kerja, orang-orang dengan siapa kita berkomunikasi semuanya mengalami perubahan yang sangat besar. Banyak perubahan dalam dunia kerja yang dinamis ini berkisar seputar memproses dan mengkomunikasikan informasi. Itu sebabnya para pemain yang paling sukses dalam dunia kerja yang baru ini adalah mereka yang mempunyai keterampilan komunikasi yang maju.

Dalam membina dan meningkatkan produktivitas pegawai, tidak terlepas dari etika kerja yang di yakini oleh individu individu tersebut. Etika merupakan seperangkat nilai tentang baik, benar, buruk dan salah yang berdasarkan prinsip- prinsip moralitas, khususnya dalam perilaku dan tindakan. Etika adalah acuan yang dipakai oleh suatu individu atau organisasi sebagai pedoman dalam melaksanakan aktivitas bisnisnya, agar kegiatan yang mereka lakukan tidak merugikan individu atau lembaga yang lainnya. Etika kerja merupakan sikap, pandangan, kebiasaan, ciriciri atau sifat mengenai cara bekerja yang dimiliki seseorang, suatu golongan atau suatu bangsa.

Etika kerja dibutuhkan ketika manusia mulai menyadari bahwa kemajuan zaman telah menyebabkan manusia semakin tersisih dari nilai-nilai kemanusiaannya (humanistik). Etika kerja yang tinggi tentunya rutinitas tidak akan membuat bosan, bahkan mampu meningkatkan produktivitas kerja. Hal yang mendasari etika kerja tinggi di antaranya keinginan untuk menjunjung tinggi mutu pekerjaan, maka individu yang mempunyai etos kerja tinggi akan 
turut serta memberikan masukan-masukan ide di tempat bekerja.

Mendisiplinkan pegawai dalam bekerja merupakan hal penting yang dilakukan oleh suatu organisasi. Hal ini diperlukan untuk meningkatkan produktivitas kerja pegawai serta tujuan organisasi dapat tercapai. Kedisiplinan diterapkan kepada pegawai agar tertib dalam bekerja dan patuh terhadap aturan yang ada pada organisasi serta pegawai tidak bertindak sesuka hati terhadap aturan yang berlaku. Kedisiplinan yang baik mencerminkan besarnya tanggung jawab seseorang terhadap tugas yang diberikan kepadanya. Hal ini dapat mendorong adanya gairan kerja, semangat kerja yang berdampak pada tercapainya tujuan organisasi. Sasaran dari disiplin kerja salah satunya adalah untuk dapat menjadikan tenaga kerja memperoleh tingkat produktivitas yang tinggi sesuai dengan harapan organisasi, dalam jangka pendek maupun jangka panjang. Melalui disiplin akan mencerminkan kekuatan, karena orang yang berhasil dalam karyanya biasanya mereka yang memiliki disiplin yang tinggi. Kedisiplinan merupakan kunci keberhasilan pada suatu organisasi.

Kedisiplinan erat kaitannya dengan tingkat kehadiran pegawai dalam bekerja. Tingkat absensi merupakan tingkat ketidakhadiran pegawai yang berkenaan dengan tugas dan kewajibannya. Pada umumnya perusahaan selalu memperhatikan pegawainya untuk datang dan pulang tepat waktu, sehingga pekerjaan tidak tertunda. Ketidakhadiran seorang pegawai akan berpengaruh terhadap produktivitas kerja, sehingga perusahaan tidak bisa mencapai tujuan secara optimal. Tingkat absensi yang baik maka dapat meningkatkan disiplin pegawai. Tingginya tingkat absensi akan mempengaruhi produktivitas pegawai dan ada kemungkinan dapat menurunkan produktivitas kerja, sehingga target yang diharapkan perusahaan tidak terpenuhi. Sebaliknya dengan rendahnya tingkat absensi akan mengakibatkan kinerja pegawai dapat meningkat dan target yang diharapkan bisa terpenuhi.

Permasalahan yang terjadi di Kantor Camat Sibolga Kota dalam hal komunikasi dantaranya pegawai jarang sekali berkomunikasi atau bertemu dengan pimpinan Camat karena Camat tidak pernah lama berda di kantor, pegawai kurang memahami aturan dan perintah dari pimpinan karena faktor tingkat pendidikan yang rendah, proses sosialisasi masih kurang baik, evaluasi pegawai tidak dilaksanakan secara transparan, sesama pegawai terkadang terjadi kesalahapahaman yang mengakibatkan pertengkaran, dan pegawai sehari-hari lebih sering berkomunikasi dengan bahasa daerah.

Selain itu mengenai etika kerja adalah masih kurang baik etika pimpinan dalam bekerja dan membimbing bawahan untuk melaksanakan tugas yang diberikan, serta antar pegawai dalam etika kerja untuk saling bekerjasama atau berinteraksi menyelesaikan tanggung jawab dari pekerjaan belum berjalan dengan baik. Selain itu kedisiplinan pegawai juga masih rendah, dimana pegawai masih kurang disiplin terutama dalam mematuhi peraturan organisasi, ada juga ditemukan pegawai yang menitip absen kepada pegawai lain, dan ada juga ditemukan pegawai yang melawan atasan.

\subsection{Batasan Masalah}

Batasan masalah digunakan untuk menghindari kesimpangsiuran dalam membahas dan menganalisis permasalahan dalam penelitian ini. Batasan masalah dalam penelitian ini adalah membahas persoalan yang berkaitan dengan komunikasi $\left(\mathrm{X}_{1}\right)$, etika kerja $\left(\mathrm{X}_{2}\right)$, kedisiplinan $\left(\mathrm{X}_{3}\right)$ dan produktivitas pegawai (Y).

\subsection{Hioptesis}

Hipotesis merupakan jawaban sementara yang diberikan peneliti yang diungkapkan dalam pernyataan yang dapat diteliti, (Sugiyono 2010:56). Berdasarkan perumusan masalah dan kerangka konseptual maka peneliti menetapkan hipotesis di dalam penelitian ini yaitu :

1) Komunikasi berpengaruh positif dan signifikan terhadap produktivitas pegawai Kantor Camat Kecamatan Sibolga Kota.

2) Etika kerja berpengaruh positif dan signifikan terhadap produktivitas pegawai Kantor Camat Kecamatan Sibolga Kota.

3) Kedisiplinan berpengaruh positif dan signifikan terhadap produktivitas pegawai Kantor Camat Kecamatan Sibolga Kota.

4) Komunikasi, Etika Kerja dan Kedisiplinan berpengaruh positif dan signifikan terhadap produktivitas pegawai Kantor Camat Kecamatan Sibolga Kota.

\subsection{Tujuan Penelitian}

Tujuan yang ingin dicapai dalam penelitian ini adalah : 
1) Untuk mengetahui dan menganalisis pengaruh komunikasi terhadap produktivitas kerja pegawai Kantor Camat Kecamatan Sibolga Kota.

2) Untuk mengetahui dan menganalisis pengaruh etika kerja terhadap produktivitas kerja pegawai Kantor Camat Kecamatan Sibolga Kota.

3) Untuk mengetahui dan menganalisis pengaruh kedisiplinan terhadap produktivitas kerja pegawai Kantor Camat Kecamatan Sibolga Kota.

4) Untuk mengetahui dan menganalisis pengaruh komunikasi, etika kerja dan kedisiplinan terhadap produktivitas kerja pegawai Kantor Camat Kecamatan Sibolga Kota.

\section{Metode Penelitian}

\subsection{Populasi}

Populasi adalah keseluruhan dari sekumpulan elemen atau objek dan subjek yang memiliki sejumlah karakteristik umum yang diminati oleh peneliti untuk dipelajari, diteliti dan kemudian ditarik kesimpulan. Dalam penelitian ini yang menjadi populasi adalah seluruh pegawai kantor Camat Sibolga Kota yang berjumlah 56 orang.

\subsection{Sampel}

Teknik pengambilan sampel dalam penelitian ini adalah sampel jenuh (saturation sampling) yaitu teknik pengambilan sampel bila semua anggota populasi digunakan sebagai sampel, dengan syarat populasi tidak banyak. Menurut Arikunto (2014:22) apabila subjek dari suatu populasi yang akan diteliti kurang dari 100, maka lebih baik diambil semua sehingga penelitiannya merupakan penelitian populasi, selanjutnya apabila subjeknya lebih dari 100 , maka diambil 10\% - $15 \%$ atau $20 \%$ - $25 \%$. Apabila objek kurang dari 100 orang lebih baik diambil semua, sehingga penelitian merupakan penelitian populasi. Dengan demikian sampel yang diambil adalah keseluruhan dari jumlah populasi yaitu 56 orang.

\subsection{Uji Normalitas}

Tujuan uji normalitas adalah ingin menguji model regresi distribusi sebuah data mengikuti atau mendekati distribusi normal, yakni distribusi data dengan bentuk lonceng. Kalau asumsi ini dilanggar maka uji statistik menjadi tidak valid. Ada dua cara untuk mendeteksi apakah data berdistribusi normal atau tidak, yaitu dengan analisis grafik dan uji statistik.

Salah satu cara untuk melihat normalitas adalah dengan melihat grafik normal plot yang membandingkan antara data observasi dengan distribusi yang mendekati distribusi normal.

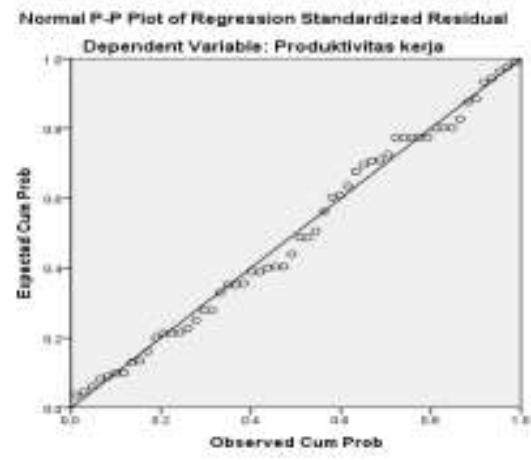

Gambar 1 Grafik Normal P-P Plot

Pada grafik Normal P-P Plot terlihat titik yang mengikuti data di sepanjang garis diagonal. Hal ini berarti data berdistribusi normal.

Untuk Uji Kolmogorov-Smirnov dilakukan melalui Non Parametric Test, hasilnya seperti pada Tabel berikut :

Tabel 1 Hasil Uji Kolmogorov-Smirnov

One-Sample Kolmogorov-Smirnov Test

\begin{tabular}{|ll|r|}
\hline & & $\begin{array}{c}\text { Unstandardized } \\
\text { Residual }\end{array}$ \\
\hline $\mathrm{N}$ & Mean & 56 \\
Normal Parameters & $0 \mathrm{E}-7$ \\
& Std. Deviation & 1.14776361 \\
Most Extreme & Absolute & .081 \\
Differences & Positive & .081 \\
& Negative & -.065 \\
Kolmogorov-Smirnov Z & & .607 \\
Asymp. Sig. (2-tailed) & & .855 \\
\hline
\end{tabular}

a. Test distribution is Normal.

b. Calculated from data. 
Pada Tabel 5.23 terlihat bahwa nilai Asymp. Sig. (2-tailed) adalah 0,855. Dengan demikian nilai Asymp. Sig. (2-tailed) 0,855 > 0,05 yang berarti variabel residual berdistribusi normal.

\subsection{Uji Multikolinearitas}

Suatu variabel menunjukkan gejala multikolinieritas bisa dilihat dari nilai Tolerance dan nilai Variance Inflation Factor (VIF). Nilai Tolerance $>0,1$ dan VIF $<10$, maka tidak terdapat multikolienaritas dalam model regresi.

Tabel 2 Hasil Uji Multikolinearitas

\begin{tabular}{|ll|r|c|}
\hline \multirow{2}{*}{ Model } & \multicolumn{2}{|c|}{ Collinearity Statistics } \\
\cline { 3 - 4 } & Tolerance & \multicolumn{1}{c|}{ VIF } \\
\hline \multicolumn{1}{|c}{ (Constant) } & & \\
1 Komunikasi & .904 & 1.107 \\
& Etika kerja & .997 & 1.003 \\
& Kedisiplinan & .906 & 1.104 \\
\hline
\end{tabular}

Hasil pengujian yang ditampilakn pada Tabel 5.24 menunjukkan bahwa semua variabel yang digunakan sebagai prediktor model regresi menunjukkan nilai Tolerance $>0,1$ dan nilai $V I F<10$. Hal ini berarti bahwa variabelvariabel bebas yang digunakan dalam penelitian tidak menunjukkan adanya gejala multikolinieritas dan dapat digunakan sebagai variabel yang saling independen.

\subsection{Uji Heteroskedostisitas}

Uji heteroskedastisitas dilakukan dengan menganalisis penyebaran titik-titik yang terdapat pada Scatterplot yang dihasilkan program SPSS dengan dasar pengambilan keputusan yaitu jika ada pola tertentu, seperti titik-titik yang ada membentuk suatu pola tertentu yang teratur (bergelombang, melebar, kemudian menyempit) maka terjadi heteroskedastisitas, sedangkan jika tidak ada pola yang jelas serta titik-titik menyebar di atas dan di bawah angka 0 pada sumbu Y, maka tidak terjadi heteroskedastisitas.

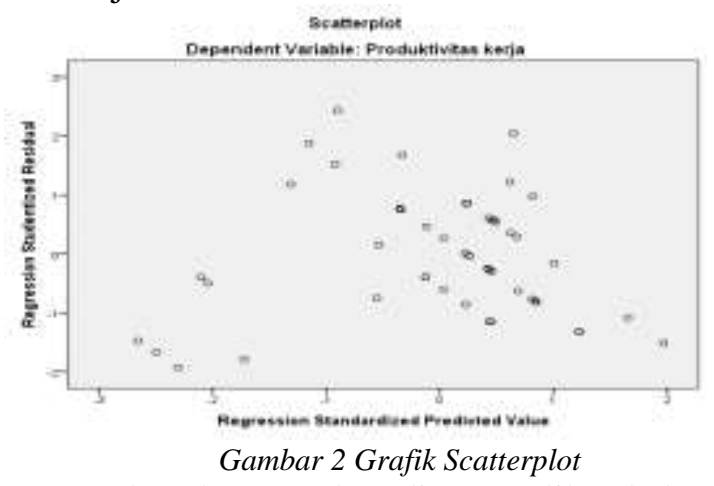

Berdasarkan gambar diatas terlihat bahwa titik-titik menyebar diatas dan dibawah 0 pada sumbu Y. Dengan demikian dapat disimpulkan bahwa tidak terjadi heteroskedostisitas dalam model regresi.

Uji heteroskedastisitas dapat juga dilakukan dengan menggunakan uji Glejser dengan cara meregresi nilai absolut residual terhadap variabel independen. Jika nilai Sig < 0,05 maka ada indikasi terjadi heteroskedastisitas, akan tetapi jika nilai $\mathrm{Sig}>$ 0,05 maka tidak terjadi heteroskedostisitas.

Tabel 3. Hasil Uji Glejser

Coefficients $^{\mathrm{a}}$

\begin{tabular}{|l|r|r|r|r|r|}
\hline \multirow{2}{*}{ Model } & \multicolumn{2}{|c|}{ Unstandardized Coefficients } & $\begin{array}{c}\text { Standardized } \\
\text { Coefficients }\end{array}$ & \multirow{2}{*}{ Sig. } & \\
\cline { 2 - 4 } & \multicolumn{1}{|c|}{$\mathrm{B}$} & \multicolumn{1}{c|}{ Std. Error } & \multicolumn{1}{c|}{ Beta } & & \\
\hline \multirow{4}{*}{ (Constant) } & 4.401 & 1.531 & & 2.874 & .006 \\
Komunikasi & -.084 & .048 & -.238 & -1.734 & .089 \\
Etika kerja & .003 & .032 & .011 & .083 & .935 \\
Kedisiplinan & -.150 & .116 & -.177 & -1.293 & .202 \\
\hline
\end{tabular}

a. Dependent Variable: Absres

Berdasarkan Tabel 3 diatas diketahui bahwa untuk variabel komunikasi $\left(\mathrm{X}_{1}\right)$ nilai signifikan 0,089 , variabel etika kerja $\left(\mathrm{X}_{2}\right)$ nilai signifikan 0,935 , dan variabel kedisiplinan $\left(X_{3}\right)$ nilai signifikan 0,202. Dengan demikian untuk ketiga variabel independen tersebut nilai signifikannya lebih besar dari 0,05 , sehingga kesimpulannya tidak terjadi heteroskedostisitas dalam model regresi.

\section{Pengujian Hipotesis}

\subsection{Analisis Regresi Linear Berganda}

Analisis regresi linear berganda ditujukan untuk mengetahui pengaruh atau hubungan 
komunikasi, etika kerja dan kedisiplinan serta produktivitas kerja pegawai, maka untuk memperoleh hasil yang lebih akurat, peneliti menggunakan bantuan program software SPSS versi 20.0, maka dihasilkan output sebagai berikut :

Tabel 4 Hasil Regresi Linear Berganda

\begin{tabular}{|c|c|c|c|}
\hline \multirow{2}{*}{\multicolumn{2}{|c|}{ Model }} & \multicolumn{2}{|c|}{$\begin{array}{c}\text { Unstandardized } \\
\text { Coefficients }\end{array}$} \\
\hline & & B & Std. Error \\
\hline \multirow{4}{*}{1} & (Constant) & -.441 & 2.942 \\
\hline & Komunikasi & .586 & .093 \\
\hline & Etika kerja & .297 & .062 \\
\hline & Kedisiplinan & .640 & .222 \\
\hline
\end{tabular}

Berdasarkan Tabel 4 diatas, jika dilihat nilai B pada kolom Unstandardized Coefficients, maka dapat dibentuk suatu model persamaan regresi sebagai berikut :

$Y=-0,441+0,586 X_{1}+0,297 X_{2}+0,640 X_{3}+e$ Interpretasi persamaan tersebut sebagai berikut

- Nilai konstanta (a) sebesar -0,441. Nilai ini mempunyai arti bahwa jika komunikasi, etika kerja dan kedisiplinan tidak ada atau bernilai nol, maka produktivitas pegawai akan turun sebesar 0,441.

- Nilai koefisien $X_{1}\left(b_{1}\right)$ sebesar 0,586. Nilai ini mempunyai arti bahwa jika komunikasi

Tabel 5 Hasil Uji Parsial (Uji t)

Coefficients $^{\mathrm{a}}$

\begin{tabular}{|c|c|c|c|c|c|c|}
\hline \multirow{2}{*}{\multicolumn{2}{|c|}{ Model }} & \multicolumn{2}{|c|}{ Unstandardized Coefficients } & \multirow{2}{*}{$\begin{array}{c}\begin{array}{c}\text { Standardized } \\
\text { Coefficients }\end{array} \\
\text { Beta }\end{array}$} & \multirow[t]{2}{*}{$\mathrm{t}$} & \multirow[t]{2}{*}{ Sig. } \\
\hline & & B & Std. Error & & & \\
\hline \multirow{4}{*}{1} & (Constant) & -.441 & 2.942 & & -.150 & .881 \\
\hline & Komunikasi & .586 & .093 & .553 & 6.311 & .000 \\
\hline & Etika kerja & .297 & .062 & .400 & 4.800 & .000 \\
\hline & Kedisiplinan & .640 & .222 & .252 & 2.879 & .006 \\
\hline
\end{tabular}

a. Dependent Variable: Produktivitas kerja

Berdasarkan Tabel 5, dapat dijelaskan sebagai berikut :

- Uji hipotesis pertama yaitu pengaruh komunikasi $\left(\mathrm{X}_{1}\right)$ terhadap produktivitas kerja pegawai $(\mathrm{Y})$, diperoleh nilai $\mathrm{t}_{\text {hitung }}$ variabel komunikasi yaitu 6,311 dengan taraf signifikansi 0,000 . Jika nilai tersebut dibandingkan dengan nilai $\mathrm{t}_{\text {tabel }}$, maka nilai $t_{\text {hitung }}(6,311)>t_{\text {tabel }}(1,675)$ dan taraf signifikasi $0,000<0,05$. Hal ini berarti bahwa komunikasi berpengaruh positif dan signifikan terhadap produktivitas kerja pegawai kantor Camat Kecamatan Sibolga naik sebesar satu satuan, maka produktivitas kerja pegawai akan naik sebesar 0,586 . Demikian pula sebaliknya.

- Nilai koefisien $X_{2}\left(b_{2}\right)$ sebesar 0,297. Nilai ini mempunyai arti bahwa jika etika kerja naik sebesar satu satuan, maka produktivitas kerja pegawai akan naik sebesar 0,297. Dengan pula sebaliknya.

- Nilai koefisien $X_{3}\left(b_{3}\right)$ sebesar 0,640. Nilai ini mempunyai arti bahwa jika kedisiplinan naik sebesar satu satuan, maka produktivitas kerja pegawai akan naik sebesar 0,640. Dengan pula sebaliknya.

Dari ketiga variabel independen tersebut, diketahui bahwa variabel kedisiplinan adalah variabel yang paling dominan mempengaruhi produktivitas kerja pegawai kantor Camat Kecamatan Sibolga Kota karena nilai koefisien regresi-nya lebih besar dari yang lain.

\subsection{Uji Signifikansi Parsial (Uji t)}

Uji parsial (uji t) digunakan untuk membuktikan pengaruh secara parsial komunikasi $\left(\mathrm{X}_{1}\right)$, etika kerja $\left(\mathrm{X}_{2}\right)$ dan kedisiplinan $\left(\mathrm{X}_{3}\right)$ terhadap produktivitas kerja (Y). Nilai $t_{\text {hitung }}$ diperoleh dari hasil SPSS, sedangkan nilai $t_{\text {tabel }}$ yang digunakan adalah nilai t pada $\alpha=0,05$ dengan derajat kebebasan $(\mathrm{df}=\mathrm{n}-\mathrm{k}=56-4=52)$ yaitu 1,675 . 
Kecamatan Sibolga Kota. Dengan demikian hipotesis kedua dapat diterima.

- Uji hipotesis ketiga yaitu pengaruh kedisiplinan $\left(\mathrm{X}_{3}\right)$ terhadap produktivitas kerja pegawai $(\mathrm{Y})$, diperoleh nilai $\mathrm{t}_{\text {hitung }}$ variabel kedisiplinan yaitu 2,879 dan taraf signifikansi 0,006. Jika nilai tersebut dibandingkan dengan nilai $t_{\text {tabel }}$, maka nilai $t_{\text {hitung }}(2,879)>t_{\text {tabel }}(1,675)$ dan taraf signifikansi $0,006<0,05$. Hal ini berarti bahwa kedisiplinan berpengaruh positif dan signifikan terhadap produktivitas kerja pegawai kantor Camat Kecamatan Sibolga Kota. Dengan demikian hipotesis ketiga dapat diterima.

\subsection{Uji Signifikansi Simultan (Uji F)}

Uji signifikasi simultan (uji F) digunakan untuk membuktikan pengaruh komunikasi $\left(\mathrm{X}_{1}\right)$, etika kerja $\left(\mathrm{X}_{2}\right)$ dan kedisiplinan $\left(\mathrm{X}_{3}\right)$ secara simultan terhadap produktivitas kerja pegawai kantor Camat Kecamatan Sibolga Kota.

Nilai $F_{\text {hitung }}$ diperoleh dari hasil pengolahan SPSS sedangkan nilai $F_{\text {tabel }}$ yang digunakan adalah nilai distribusi $F$ dengan derajat kebebasan :

$\mathrm{df}_{1}=\mathrm{k}-1=4-1=3$

$\mathrm{df}_{2}=\mathrm{n}-\mathrm{k}=56-4=52$

Maka $F_{\text {tabel }}$ yang digunakan adalah $\mathrm{F}_{0,05}(3 ; 52)$ yaitu 2,783 .

Tabel 6. Hasil Uji Simultan (Uji F)

\begin{tabular}{|c|c|c|c|c|c|c|}
\hline \multicolumn{7}{|c|}{ ANOVA $^{\mathrm{a}}$} \\
\hline & & $\begin{array}{l}\text { Sum of } \\
\text { Squares }\end{array}$ & df & Mean Square & $\mathrm{F}$ & Sig. \\
\hline \multirow{3}{*}{1} & Regression & 128.402 & 3 & \multirow{3}{*}{$\begin{array}{r}42.801 \\
1.393\end{array}$} & \multirow[t]{3}{*}{30.718} & \multirow[t]{3}{*}{$.000^{\mathrm{b}}$} \\
\hline & Residual & 72.455 & 52 & & & \\
\hline & Total & 200.857 & 55 & & & \\
\hline
\end{tabular}

Berdasarkan Tabel 6 diatas, diperoleh nilai $\mathrm{F}_{\text {hitung }}$ sebesar 30,718 dengan nilai signifikansi 0,000 . Selanjutnya nilai $F_{\text {hitung }}$ dibandingkan dengan nilai $\mathrm{F}_{\text {tabel }}$, maka diperoleh $\mathrm{F}_{\text {hitung }}$ $(30,718)>F_{\text {tabel }}(2,783)$ dan taraf signifikasi $0,000<0,05$. Hal ini menunjukkan bahwa komunikasi, etika kerja dan kedisiplinan secara simultan berpengaruh positif dan signifikan terhadap produktivitas kerja pegawai kantor Camat Kecamatan Sibolga Kota. Dengan demikian hipotesis keempat dapat diterima.

\subsection{Uji Determinan $\left(\boldsymbol{R}^{2}\right)$}

Koefisien determinan mengukur seberapa jauh kemampuan model dalam menerangkan variasi variabel independen. Nilainya adalah 0 1. Semakin mendekati nol berarti model regresi semakin tidak baik atau model dalam menjelaskan dengan sangat terbatas, dan sebaliknya semakin mendekati satu, maka model semakin baik.

Tabel 7 Hasil Uji Determinan

Model Summary

\begin{tabular}{|l|c|r|c|c|}
\hline Model & $\mathrm{R}$ & $\mathrm{R}$ Square & $\begin{array}{c}\text { Adjusted R } \\
\text { Square }\end{array}$ & $\begin{array}{c}\text { Std. Error of } \\
\text { the Estimate }\end{array}$ \\
\hline 1 & $.800^{\mathrm{a}}$ & .639 & .618 & 1.180 \\
\hline
\end{tabular}

Besarnya koefesien determinasi dapat dilihat pada kolom Adjusted $R$ Square yaitu sebesar 0,618. Nilai ini berarti bahwa produktivitas pegawai mampu dipengaruhi oleh komunikasi, etika kerja dan kedisiplinan sebesar 61,8\%. Sedangkan sisanya sebesar $38,2 \%$ dipengaruhi variabel lain yang tidak diteliti dalam penelitian ini.

\section{Evaluasi}

Berdasarkan hasil uji hipotesis pertama diketahui bahwa variabel mempunyai nilai $t_{\text {hitung }}$ $(6,311)>t_{\text {tabel }}(1,675)$ dan taraf signifikasi $0,000<0,05$. Artinya bahwa komunikasi berpengaruh positif dan signifikan terhadap produktivitas kerja pegawai kantor Camat Kecamatan Sibolga Kota. Selain itu, variabel komunikasi memberikan kontribusi positif terhadap produktivitas kerja, sebagaimana hasil analisis regresi linear berganda bahwa nilai $\beta$ variabel komunikasi adalah 0,586. Hal ini menunjukkan bahwa pegawai Kantor Camat Kecamatan Sibolga Kota dapat meningkatkan produktivitas kerjanya melalui komunikasi. 
Artinya semakin baik komunikasi dalam organisasi, maka akan semakin meningkat produktivitas kerja pegawai.

Komunikasi merupakan proses pemindahan suatu informasi dari seseorang kepada orang lain yaitu pengirim (sender) kepada penerima (receiver) agar dapat tercipta suatu persepsi atau pemahaman dari kedua belah pihak. Seorang pimpinan perusahaan di dalam melakukan kegiatan-kegiatan manajemen memerlukan komunikasi dengan bawahannya baik secara horizontal, maupun vertikal. Komunikasi tersebut dipergunakan di dalam penyampaian pesan yang disampaikan oleh manajemen tingkat atas dengan tujuan dapat diterima baik oleh manajemen tingkat menengah, maupun manajemen tingkat bawah.

Komunikasi merupakan dasar adanya kerja sama, jika dilakukan dengan baik, akan membantu perusahaan dalam mencapai tujuan. Untuk mencapai tujuan dari perusahaan tersebut perlu adanya komunikasi yang efektif sebagai proses interaksi atau hubungan satu sama lain yang dikehendaki agar diterima dan dimengerti antara atasan dengan bawahan maupun dengan atasannya. Hasil penelitian ini sejalan dan menguatkan penelitian terdahulu oleh Mandala (2014) dan Aning Kesuma Putri, Siti Holia (2015), dimana mereka menyimpulkan bahwa komunikasi berpengaruh terhadap produktivitas karyawan.

Selanjutnya berdasarkan uji hipotesis kedua diketahui bahwa variabel etika kerja mempunyai nilai $t_{\text {hitung }}(4,800)>t_{\text {tabel }}(1,675)$ dan taraf signifikansi $0,000<0,05$. Artinya bahwa etika kerja berpengaruh positif dan signifikan terhadap produktivitas kerja pegawai kantor Camat Kecamatan Sibolga Kota. Selain itu, variabel etika kerja memberikan kontribusi positif terhadap produktivitas kerja, sebagaimana hasil analisis regresi linear berganda bahwa nilai $\beta$ variabel etika kerja adalah 0,297. Hal ini menunjukkan bahwa pegawai Kantor Camat Kecamatan Sibolga Kota dapat meningkatkan produktivitas kerjanya melalui etika kerja. Dengan kata lain semakin baik etika kerja pegawai, maka akan semakin baik pula produktivitas kerjanya.

Etika kerja merupakan suatu hal yang sangat penting untuk digunakan oleh suatu individu atau perusahaan sebagai pedoman dalam menjalankan aktivitas bisnisnya, guna aktivitas yang dilakukan tidak merugikan dirinya sendiri maupun orang lain. Etika kerja sebagai semangat kerja yang didasari oleh nilai- nilai atau norma-norma tertentu. Hal ini sesuai dengan pendapat Supardan (2013:57) yang menyatakan bahwa etika kerja adalah suatu semangat kerja yang dimiliki oleh masyarakat untuk mampu bekerja lebih baik guna memperoleh nilai hidup mereka. Etika kerja menentukan penilaian manusia yang diwujudkan dalam suatu pekerjaan.

Menurut Ernawan (2013:83) etika kerja merupakan sikap, pandangan, kebiasaan, ciriciri atau sifat mengenai cara bekerja yang dimiliki seseorang, suatu golongan atau suatu bangsa. Etika kerja yang tinggi tentunya rutinitas tidak akan membuat bosan, bahkan mampu meningkatkan prestasi kerjanya atau kinerja. Hal yang mendasari etika kerja tinggi di antaranya keinginan untuk menjunjung tinggi mutu pekerjaan, maka individu yang mempunyai etos kerja tinggi akan turut serta memberikan masukan-masukan ide di tempat bekerja. Hal ini menunjukkan produktivitas yang tinggi. Hasil penelitian ini menguatkan penelitian terdahulu oleh Fitriyan (2015) yang menyatakan bahwa etika kerja berpengaruh positif dan signifikan terhadap produktifitas kerja karyawan.

Selanjutnya berdasarkan uji hipotesis ketiga diketahui bahwa variabel kedisiplinan mempunyai nilai $t_{\text {hitung }}(2,879)>t_{\text {tabel }}(1,675)$ dan taraf signifikansi $0,006<0,05$. Artinya bahwa kedisiplinan berpengaruh positif dan signifikan terhadap produktivitas kerja pegawai kantor Camat Kecamatan Sibolga Kota. Selain itu, variabel kedisiplinan memberikan kontribusi positif terhadap produktivitas kerja, sebagaimana hasil analisis regresi linear berganda bahwa nilai $\beta$ variabel kedisiplinan adalah 0,640. Hal ini menunjukkan bahwa pegawai Kantor Camat Kecamatan Sibolga Kota dapat meningkatkan produktivitas kerjanya melalui kedisiplinan. Dengan kata lain semakin baik disiplin pegawai, maka akan semakin baik pula produktivitas kerjanya.

Hasibuan (2017:193-194) menjelaskan bahwa kedisiplinan merupakan kesadaran dan kesediaan seseorang menaati semua peraturan perusahaan dan norma-norma sosial yang berlaku. Sedangkan kesadaran adalah sikap seseorang yang secara sukarela menaati semua peraturan dan sadar akan tugas dan tanggung jawabnya. Kemudian kesediaan adalah suatu sikap, tingkah laku, dan perbuatan seseorang yang sesuai dengan peraturan perusahaan, baik yang tertulis maupun tidak. Disiplin mengacu pada pola tingkah laku pegawai, umumnya 
disiplin kerja karyawan dapat diukur dari ketaatan terhadap aturan waktu, ketaatan terhadap peraturan organisasi, dan ketaatan terhadap aturan perilaku dalam pekerjaan.

Asumsi penulis pada awal terbukti benar yang menganggap bawasannya saat kedisiplinan dan peraturan ditegakkan dan dilaksanakan dengan baik maka karyawan akan bekerja dengan baik sehingga berjalan optimal dan memberikan hasil yang baik. Hasil penelitian ini mendukung penelitian terdahulu yang dilakukan oleh Safitri Indriyani (2015) dan Miftahul Fauzi (2016) yang menyatakan bahwa kedisiplinan berpengaruh signifikan secara parsial terhadap produktivitas karyawan.

Berdasarkan hasil uji hipotesis keempat diketahui bahwa komunikasi, etika kerja dan kedisiplinan mempunyai nilai $\mathrm{F}_{\text {hitung }}(30,718)>$ $\mathrm{F}_{\text {tabel }}(2,783)$ dan taraf signifikasi $0,000<0,05$. Artinya bahwa komunikasi, etika kerja dan kedisiplinan secara simultan berpengaruh positif dan signifikan terhadap produktivitas kerja pegawai kantor Camat Kecamatan Sibolga Kota. Dengan kata lain apabila komunikasi, etika kerja dan kedisiplinan pegawai berjalan dengan baik, maka produktivitas pegawai akan meningkat.

Hasil penelitian ini menunjukkan bahwa produktivitas kerja pegawai Kantor Camat Kecamatan Sibolga Kota mampu dipengaruhi oleh komunikasi, etika kerja dan kedisiplinan sebesar $61,8 \%$, sedangkan sisanya sebesar $31,2 \%$ dipengaruhi variabel lain yang tidak diteliti dalam penelitian ini. Dari ketiga variabel yang mempengaruhi produktivitas kerja tersebut diketahui bahwa variabel kedisiplinan merupakan variabel yang paling dominan berpengaruh terhadap produktivitas kerja dimana nilai koefisien regresi-nya lebih besar dibandingkan yang lain.

Produktivitas kerja sangatlah penting sebagai alat pengukur keberhasilan dalam menjalankan aktivitas karena dapat memberikan pengaruh terhadap pencapaian tujuan. Oleh sebab itu penting bagi perusahaan untuk meningkatkan dan memelihara produktivitas kerja agar tujuan perusahaan dapat tercapai, diantaranya melalui komunikasi yang efektif, etika kerja yang baik dan kedisiplinan. Hasil penelitian ini sesuai dengan teori yang kemukakan Ravianto menyebutkan bahwa faktor-faktor yang mempengaruhi produktivitas kerja yaitu pendidikan, ketrampilan, disiplin, sikap dan etika kerja, motivasi, kesehatan, tingkat penghasilan, jaminan sosial, dan sarana produksi dalam sebuah perusahaan atau organisasi. Serta sesuai juga dengan teori dari Suparno yang menyebutkan bahwa bahwa faktor yang mempengaruhi produktivitas yaitu, pertama, faktor pendorong dan jaminan masa depan karyawan yang meliputi motivasi, disiplin, ketrampilan, jenjang karier, gizi dan kesehatan, gaji atau upah, kesejahteraan, lingkungan kerja, dan jaminan sosial. Kedua, faktor hubungan industrial yaitu hubungan antara perusahaan dengan karyawan, yang melibatkan serikat buruh, dan departemen tenaga kerja, dan instansi terikat lainnya.

\section{Kesimpulan}

Berdasarkan hasil analisis yang telah dilakukan, maka penulis dapat mengambil beberapa kesimpulan sebagai berikut :

1) Komunikasi berpengaruh positif dan signifikan terhadap produktivitas kerja pegawai Kantor Camat Kecamatan Sibolga Kota.

2) Etika kerja berpengaruh positif dan signifikan terhadap produktivitas kerja pegawai Kantor Camat Kecamatan Sibolga Kota.

3) Kedisiplinan berpengaruh positif dan signifikan terhadap produktivitas kerja pegawai Kantor Camat Kecamatan Sibolga Kota.

4) Komunikasi, etika kerja dan kedisiplinan secara simultan berpengaruh positif dan signifikan terhadap produktivitas kerja pegawai Kantor Camat Kecamatan Sibolga Kota.

\section{DAFTAR PUSTAKA}

Agoes, Sukrisno dan I Cenik Ardana. (2014). Etika Bisnis dan Profesi. Jakarta : Salemba Empat.

Ali, Abbas. (2011). "Scaling of IslamicRork Ethic". Journal of Social Pshycolgy. (hlm 679-581).

Arikunto, Suharsimi. (2014). Prosedur Penelitian Suatu Pendekatan Praktik. Jakarta : Rineka Cipta.

Bertens, K. (2011). Etika. Jakarta : Gramedia Pustaka Utama.

Ernawan, R Erni. (2013). Etika Bisnis. Cetakan kedua, Bandung : Alfabeta.

Febrianto, dkk. (2016). "Pengaruh Insentif, Komunikasi Dan Lingkungan Kerja Terhadap Kepuasan Kerja Dan Implikasinya Terhadap Produktivitas Kerja Di CV. Duta Karya Semarang". Journal Of Management. 
Fakultas Ekonomika dan Bisnis Universitas Pandanaran Semarang.

Fitriyan. (2015). "Pengaruh Etika Kerja Dan Motivasi Kerja Islam Terhadap Produktivitas Kerja Karyawan (Studi Pada Karyawan Bank BNI Syari'ah Cabang Semarang)". Skripsi. Fakultas Syari'ah Institut Agama Islam Negeri Walisongo Semarang.

Hasibuan, Malayu SP. (2017). Manaemen Sumber Daya Manusia. Jakarta : PT. Bumi Aksara.

Indriyani, Safitri. 2015. "Pengaruh Pelatihan Kerja dan Disiplin Kerja Terhadap Produktivitas Kerja Karyawan Pada PT. Paradise Island Furniture". JM-Vol 5 No. 1.

Mandala, Zulhafis. (2014). "Pengaruh Komunikasi dan Koordinasi Terhadap Produktivitas Kerja Pegawai H. Abdul Manan Simatupang Kisaran Kabupaten Asahan". Jurnal Ilmu Kedokteran dan Kesehatan, Volume 1 Nomor 2, April 2014.

Mankunegara, Anwar Prabu. (2015). Manajemen Sumber Daya Manusia Perusahaan. Cetakan keduabelas. Bandung : Remaja Rosdakarya.

Notoatmodjo, S. (2015). Metodologi Penelitian Kesehatan. Jakarta : Rineka Cipta.

Aning Kesuma Putri, Siti Holia. (2015). "Pengaruh Komunikasi dan Lingkungan Kerja Terhadap Produktivitas Kerja Karyawan Pada PT. Perkebunan Hasil Musi Lestari Jayaloka Kabupaten Musi Rawas". Jurnal Profit Volume 2, Nomor 2, November 2015.

Ravianto, J. Putra. 2014. Produktivitas dan Pengukuran, Jakarta : Binaman Aksara.

Rudito, Bambang dan Melia Famiola. (2013). Etika Bisnis dan Tanggung Jawab Sosial, Perusahaan di Indonesia. Bandung : Rekayasa Sains.

Siagian, Sondang P. (2014). Manajemen Sumber Daya Manusia. Jakarta : Bumi Aksara.

Sinamo, Jansen. (2012). Ethos Kerja Profesional. Jakarta : Institut Dharman Mahardika.

Sinungan, Muchdarsyah. (2014). Produktivitas : Apa dan Bagaimana. Cetakan ke-9. Jakarta : Bumi Aksara.

Supardan Dadang. (2013). Pengantar Ilmu Sosial Sebuah Kajian Pendekatan Struktural. Cetakan Kedua. Jakarta : Bumi Aksara.

Sopiah. (2013). Perilaku Organisasi. Yogyakarta : Andi.
Sugiyono. (2013). Metode Penelitian Bisnis. Bandung: CV. Alfabeta.

Suranto, AW. (2015). Komunikasi Sosial. Yogyakarta : Graha Ilmu.

Sutrisno. Edi. (2016). Manajemen Sumber Daya Manusia. Jakarta : Kencana Prenada Media Group.

Terry, George R. (2013). Dasar-Dasar Manajemen, (Terjemahan : G.A Ticoalu). Bandung: CV. Alfabeta.

Wibowo. (2017). Manajemen Kinerja. Edisi Kelima. Jakarta : Raja Grafindo.

Widodo, Untung. (2011). "Pengaruh Komunikasi dan Disiplin Kerja Terhadap Kinerja Karyawan Pada SMK Pelita Nusantara 1 - 2 Semarang”. Fokus Ekonomi Vol. 6 No. 2 Desember 2011 : 99 - 114.

Wursanto. (2011). Dasar-DasarManajemen Personalia. Jakarta : Dian Pustaka. 